\title{
Lysinibacillus macroides sp. nov., nom. rev.
}

Correspondence

An Coorevits

an.coorevits@hogent.be
An Coorevits, ${ }^{1,2}$ Anna E. Dinsdale, ${ }^{3}$ Jeroen Heyrman, ${ }^{2}$ Peter Schumann, ${ }^{4}$ Anita Van Landschoot, ${ }^{1,2}$ Niall A. Logan ${ }^{3}$ and Paul De Vos ${ }^{2}$

\author{
${ }^{1}$ Laboratory of Biochemistry and Brewing, Faculty of Applied Engineering Sciences, \\ University College Ghent, Valentin Vaerwyckweg 1, 9000 Ghent, Belgium \\ ${ }^{2}$ Laboratory of Microbiology (LM-UGent), Department of Biochemistry and Microbiology, \\ Ghent University, K.L. Ledeganckstraat 35, 9000 Ghent, Belgium \\ ${ }^{3}$ Department of Biological and Biomedical Sciences, Glasgow Caledonian University, \\ Cowcaddens Road, Glasgow G4 OBA, UK \\ ${ }^{4}$ DSMZ - German Collection of Microorganisms and Cell Cultures, Inhoffenstr. 7B, \\ D-38124 Braunschweig, Germany
}

\begin{abstract}
'Bacillus macroides' ATCC $12905^{\top}$ (=DSM 54 ${ }^{\top}=$ LMG $18474^{\top}$ ), isolated in 1947 from cow dung, was not included in the Approved Lists of Bacterial Names and so it lost standing in bacteriological nomenclature. Reinvestigation of the strain, including DNA-DNA relatedness experiments, revealed that 'Bacillus macroides' is genomically distinct from its closest relatives Lysinibacillus xylanilyticus, Lysinibacillus boronitolerans and Lysinibacillus fusiformis (as determined by $16 \mathrm{~S}$ rRNA gene sequence analysis, with pairwise similarity values of 99.2, 98.8 and $98.5 \%$, respectively, with the type strains of these species). Further analysis showed that 'Bacillus macroides' shares the A4 $\alpha$ L-Lys-D-Asp peptidoglycan type with other members of the genus Lysinibacillus and can thus be attributed to this genus. These results, combined with additional phenotypic data, justify the description of strain LMG $18474^{\top}\left(=\mathrm{DSM} 54^{\top}=\mathrm{ATCC}^{\top}\right.$ $12905^{\top}$ ) as Lysinibacillus macroides sp. nov., nom. rev.
\end{abstract}

Pringsheim \& Robinow (1947) gave the provisional name 'Lineola longa' to a very large, Gram-negative, filamentous bacterium of unusual morphology. Later, Pringsheim (1950) described the genus Lineola with ' $L$. longa' as the type species, and mentioned that a subculture of ' $L$. longa' had been deposited in the American Type Culture Collection (ATCC). Bennett \& Canale-Parola (1965) reinvestigated the type strain (ATCC $12905^{\mathrm{T}}$ ) and they found that its morphology corresponded closely to the earlier description. However, the strain formed endospores under suitable conditions and stained Gram-positive. Bennett \& Canale-Parola (1965) mentioned that they sent a culture to Pringsheim, who recognized it as ' $L$. longa'. In addition, Pringsheim confirmed the formation of endospores in stock cultures of ' $L$. longa' kept in his laboratory. After confirmation of strain originality, Bennett \& CanaleParola (1965) concluded that ' $L$. longa' should be renamed 'Bacillus macroides'. The species was not included in the Approved Lists of Bacterial Names (Skerman et al., 1980) because there were too few strains available and so no adequate description existed at the time the lists were compiled. As a consequence, it lost standing in bacteriological nomenclature. The species was included in the

Five supplementary figures and a supplementary table are available with the online version of this paper.
Species Incertae Sedis section of Bacillus in Bergey's Manual (Logan \& De Vos, 2009), with the comment that the characters of ' $B$. macroides' conform to those of Bacillus sphaericus (recently reclassified as Lysinibacillus sphaericus; Ahmed et al., 2007) with the exception of endospore morphology, the endospore of ' $B$. macroides' being described as frankly oval and scarcely distending the sporangium.

At the beginning of this study, two strains named ' $B$. macroides' were available: ATCC $12905^{\mathrm{T}}\left(=\mathrm{DSM} 54^{\mathrm{T}}=\mathrm{LMG}\right.$ $18474^{\mathrm{T}}$ ), on which the original description was based, and NCIMB 8796 (=NCDO 1661=LMG 18508), of which a 16S rRNA gene sequence was available (EMBL accession number X70312). A discrepancy was observed between these two strains. On the one hand, Xu \& Côté (2003) demonstrated that ' $B$. macroides' strain ATCC $12905^{\mathrm{T}}$ shared highest 3 ' end 16S rRNA gene and $5^{\prime}$ end 16S-23S ITS sequence similarity with Bacillus fusiformis (= Lysinibacillus fusiformis; Ahmed et al., 2007) and B. sphaericus (=L. sphaericus; Ahmed et al., 2007); on the other hand, 'B. macroides' strain NCIMB 8796 showed an almost identical 16S rRNA gene sequence to Bacillus simplex LMG $11160^{\mathrm{T}}$. In a polyphasic study by Heyrman et al. (2005), including DNA-DNA relatedness experiments, it was shown that ' $B$. macroides' strain NCIMB 8796 indeed belongs to B. simplex and should be renamed accordingly. Since the characteristics of ' $B$. 
macroides' strain ATCC $12905^{\mathrm{T}}$ conform to the original description of the species, it can be concluded that this strain is the true ' $B$. macroides'. Ahmed et al. (2007) transferred the closest relatives of ' $B$. macroides' to Lysinibacillus as $L$. sphaericus and L. fusiformis, and also described the novel species Lysinibacillus boronitolerans. Miwa et al. (2009) described another novel species of this genus, Lysinibacillus parviboronicapiens, isolated from soil, and Lee et al. (2010) proposed a xylan-degrading strain isolated from forest humus as Lysinibacillus xylanilyticus. Recently, Jung et al. (2010a) described the transfer of two Bacillus species, Bacillus odysseyi and Bacillus massiliensis, to the genus Lysinibacillus, and described a further novel species, Lysinibacillus sinduriensis, isolated from tidal flat sediment samples taken from the Yellow Sea, Korea. However, this publication was retracted prior to print, due to difficulties with chemotaxonomic characterization of the type strain of L. sinduriensis (Jung et al., 2010b).

The genus Lysinibacillus is characterized by a distinctive peptidoglycan composition (type A $4 \alpha$ L-Lys-D-Asp). In this study, we investigated whether LMG $18474^{\mathrm{T}}$ (=ATCC $12905^{\mathrm{T}}=\mathrm{DSM} 54^{\mathrm{T}}$ ) deserves separate species status, following the minimal standards for description of new taxa of aerobic endospore-forming bacteria, as recommended by Logan et al. (2009). Furthermore, given the recent taxonomic rearrangements, we also investigated whether LMG $18474^{\mathrm{T}}$ has the phenotypic traits that characterize members of the genus Lysinibacillus. For clarity, LMG $18474^{\mathrm{T}}$ is hereinafter referred to as Lysinibacillus macroides.

To confirm authenticity of strain LMG $18474^{\mathrm{T}}$, the subculture used in this study, DNA and MALDI fingerprints of LMG $18474^{\mathrm{T}}$, ATCC $12905^{\mathrm{T}}$ and DSM $54^{\mathrm{T}}$ were generated and, as can be seen in Fig. S1 (available in IJSEM Online), these profiles proved to be identical. Based on the literature discussed above, the $16 \mathrm{~S}$ rRNA gene sequence of L. macroides strain LMG $18474^{\mathrm{T}}$ (AJ628749) was compared with the 16S rRNA gene sequences of type strains of all described Bacillus and Lysinibacillus species, as well as with members of the genera Kurthia and Caryophanon. Pairwise similarity values were calculated using the ARB software (Ludwig et al., 2004) and were found to be highest with members of the genus Lysinibacillus, i.e. $99.2 \%$ with $L$. xylanilyticus XDB9 ${ }^{\mathrm{T}}, 98.8 \%$ with $L$. boronitolerans $10 \mathrm{a}^{\mathrm{T}}$, $98.5 \%$ with $L$. fusiformis NRRL NRS- $350^{\mathrm{T}}, 97.9 \%$ with $L$. sphaericus NRRL B- $23268^{\mathrm{T}}$ and $97.5 \%$ with $L$. parviboronicapiens BAM $-582^{\mathrm{T}}$. Phylogenetic trees based on these 16S rRNA gene sequences were constructed by aligning all sequences based on the integrated aligner of the ARB software (Ludwig et al., 2004). Refinement of the alignment was obtained by applying the bacterial position variability filter integrated in ARB, resulting in a final alignment of 1402 positions. The alignment was then exported to MEGA5 software (Tamura et al., 2011) to construct neighbourjoining, maximum-likelihood and maximum-parsimony trees. The jModelTest 0.1.1 program (Posada, 2008) was applied to the dataset to determine the best fit evolutionary model, and the resulting parameters, namely the GTR evolutionary model with 0.581 as the proportion of invariable sites value and a gamma shape value of 0.418 , were applied for tree construction where appropriate. Bootstrap analysis based on 1000 replicates was performed on all three types of trees to assess the reliability of the clusters. The resulting neighbour-joining tree is represented in Fig. 1; maximum-parsimony consensus and maximum-likelihood trees are shown in Figs S2 and S3, respectively (available in IJSEM Online). In all three trees, L. macroides, L. boronitolerans and L. xylanilyticus grouped together and were then joined by a group including $L$. sphaericus, L. fusiformis and L. parviboronicapiens, both subgroups forming a monophyletic cluster of Lysinibacillus species. Based on these findings, a DNA-DNA relatedness study and determinations of the DNA G + C content were performed on L. macroides LMG $18474^{\mathrm{T}}$, L. boronitolerans DSM $17140^{\mathrm{T}}$, L. xylanilyticus CCUG $57438^{\mathrm{T}}$, L. sphaericus LMG $7134^{\mathrm{T}}$, L. parviboronicapiens KCTC $13154^{\mathrm{T}}$ and $L$. fusiformis LMG $9816^{\mathrm{T}}$. For determination of the DNA $\mathrm{G}+\mathrm{C}$ content and DNA-DNA hybridization, about $1 \mathrm{~g}$ biomass was harvested from tryptone soy agar (TSA) plates and DNA was purified as described by Logan et al. (2000). DNA-DNA hybridization was performed using a modification of the microplate method described by Ezaki et al. (1989), as described by Willems et al. (2001). A hybridization temperature of $32{ }^{\circ} \mathrm{C}$ was used (calculated with correction for the presence of $50 \%$ formamide). The DNA $\mathrm{G}+\mathrm{C}$ content was determined by HPLC (Mesbah et al., 1989), using further specifications given by Logan et al. (2000). Mean DNA-relatedness values of $L$. macroides towards the type strains of $L$. xylanilyticus, L. boronitolerans, L. fusiformis, L. sphaericus and L. parviboronicapiens were $35,31,31,24$ and $21 \%$, respectively. This indicates that LMG $18474^{\mathrm{T}}$ at least represents a separate genospecies. Type strains of the closely related species $L$. sphaericus and L. fusiformis showed a DNA-DNA relatedness value of $25.2 \%$, confirming their separate species status. The DNA G $+C$ value of $L$. macroides was $38.2 \mathrm{~mol} \%$ (mean value of three determinations), which is highly similar to that of L. sphaericus and L. fusiformis (both $37.2 \mathrm{~mol} \%$ ). Bennett \& Canale-Parola (1965) reported a DNA G+C value of $42.0 \mathrm{~mol} \%$ for $L$. macroides, which is rather higher than the value obtained in this study.

Purified peptidoglycan preparations were obtained after disruption of cells by shaking with glass beads and subsequent trypsin digestion, according to the method of Schleifer (1985). The amino acids and peptides in the cell wall hydrolysates [(i) $6 \mathrm{M} \mathrm{HCl}, 120{ }^{\circ} \mathrm{C}, 16 \mathrm{~h}$; (ii) $4 \mathrm{M} \mathrm{HCl}$, $100{ }^{\circ} \mathrm{C}, 16 \mathrm{~h}$; (iii) $4 \mathrm{M} \mathrm{HCl}, 100{ }^{\circ} \mathrm{C}, 45 \mathrm{~min}$ ] were analysed by two-dimensional ascending TLC on cellulose plates by using previously described solvent systems (Schleifer, 1985). The molar ratios of the amino acids were determined by GC and GC-MS of $N$-heptafluorobutyryl amino acid isobutyl esters (MacKenzie, 1987; Groth et al., 1996). Cell material of L. macroides LMG $18474^{\mathrm{T}}$ and L. boronitolerans DSM $17140^{\mathrm{T}}$ was obtained after growth 


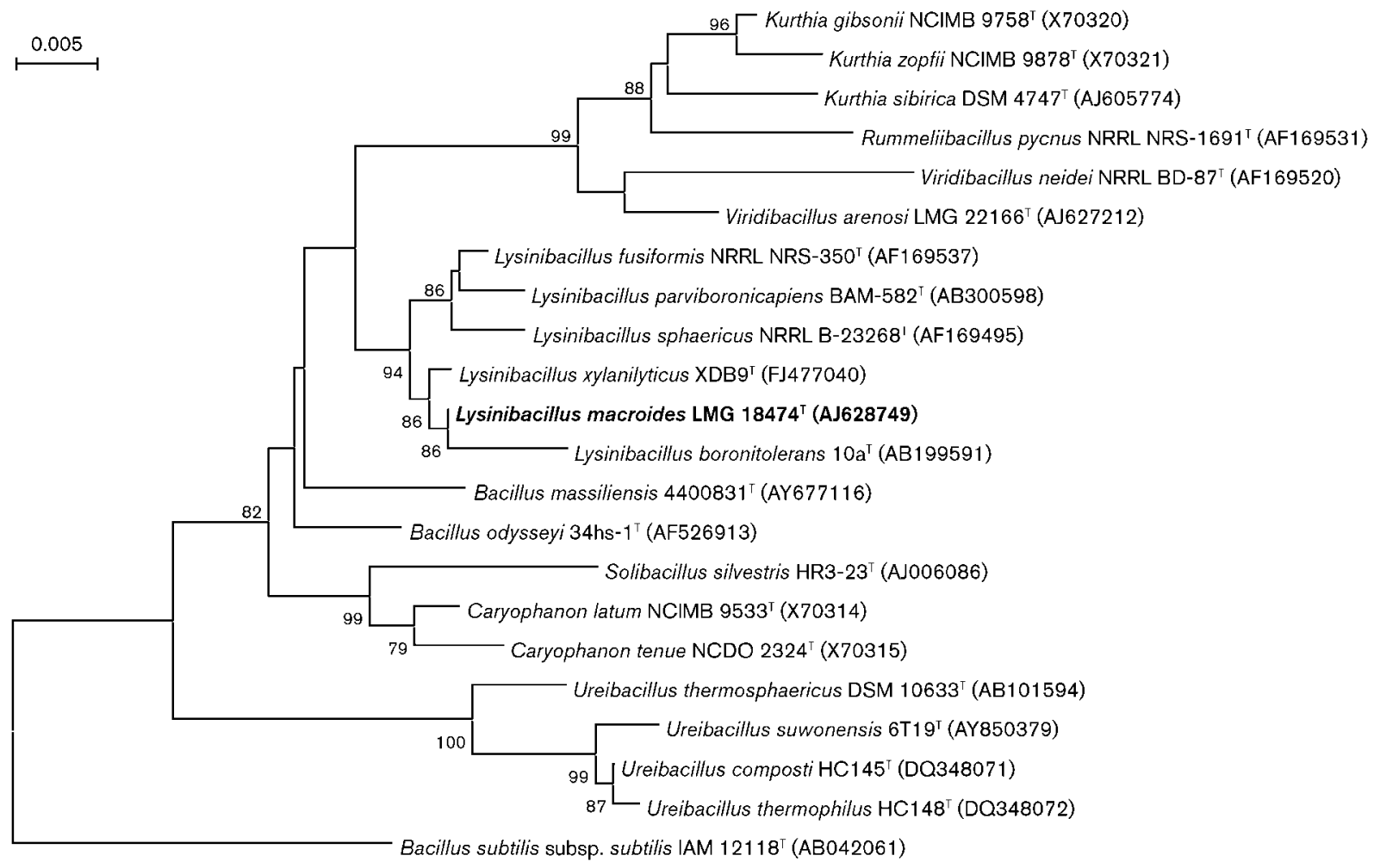

Fig. 1. Neighbour-joining tree based on multiple alignment of partial 16S rRNA gene sequences (1402 positions were taken into account). Bootstrap values above $70 \%$ (based on 1000 replications) are represented at the branch points. Accession numbers of the sequences are shown in parentheses. The 16S rRNA gene sequence of Bacillus subtilis subsp. subtilis strain IAM $12118^{\top}$ (AB042061) was included as an outgroup to root the tree. Bar, 0.005 substitutions per nucleotide position.

on TSA (Oxoid) for $24 \mathrm{~h}$ at $28^{\circ} \mathrm{C}$. Polar lipids were subsequently extracted and separated by using twodimensional TLC according to Tindall (1990a, b). The total lipid profiles were visualized by spraying with molybdatophosphoric acid and further characterized by spraying with ninhydrin (specific for amino groups), molybdenum blue (specific for phosphates) and $\alpha$ naphthol (specific for sugars). GC analysis of fatty acid methyl esters was performed starting from cells grown on plates containing $30 \mathrm{~g}$ trypticase soy broth (BBL, Becton Dickinson) supplemented with $15 \mathrm{~g}$ Bacto Agar (Difco) per litre of distilled water, and the plates were incubated for $24 \mathrm{~h}$ at $28{ }^{\circ} \mathrm{C}$. Fatty acid methyl ester extraction and analysis were performed as described by Vancanneyt et al. (1996). For determination of cell and sporangial morphologies, isolates were grown on TSA at $\mathrm{pH} 7$ and $30{ }^{\circ} \mathrm{C}$ for $24-48 \mathrm{~h}$ and further observed as described by Logan et al. (2000). Strains were characterized phenotypically as described by Logan \& De Vos (2009); anaerobic growth was tested using a GasPak jar with a methylene blue indicator strip, and an aerobic control culture. L. macroides strain LMG $18474^{\mathrm{T}}$ was tested for carbon source assimilation using the Biotype 100 Gallery (bioMérieux), according to Logan et al. (2002). Additionally, L. macroides LMG $18474^{\mathrm{T}}$, L. boronitolerans DSM $17140^{\mathrm{T}}$, L. sphaericus LMG $7134^{\mathrm{T}}$, L. fusiformis LMG
$9816^{\mathrm{T}}$ and L. xylanilyticus CCUG $57438^{\mathrm{T}}$ were analysed using the Biolog Gen III characterization system (Biolog) following protocol $\mathrm{B}$ according to the manufacturer's instructions.

Peptidoglycan analysis revealed that strain LMG $18474^{\mathrm{T}}$ has the A $4 \alpha$ L-Lys-D-Asp peptidoglycan type, confirming the result of an earlier analysis (Schleifer \& Kandler, 1972), and in agreement with the description of Lysinibacillus (Ahmed et al., 2007). Kurthia species are also characterized by this type of cell wall, with lysine and aspartic acid as the diagnostic amino acids (Albert et al., 2007); however, members of this genus can easily be differentiated from members of the genus Lysinibacillus by their inability to form endospores. Members of the genus Ureibacillus were characterized by an A4 $\alpha$ L-Lys-D-Asn type of peptidoglycan (Fortina et al., 2001), but the recently described species Ureibacillus composti and Ureibacillus thermophilus show the A4 $\alpha$ L-Lys-D-Asp peptidoglycan type (Weon et al., 2007), as observed in Lysinibacillus species. Albert et al. (2007) transferred three Bacillus species, Bacillus arvi, Bacillus arenosi and Bacillus neidei, to the novel genus Viridibacillus based on discriminative chemotaxonomic markers. Analysis of cell wall type revealed that Viridibacillus arvi DSM $16317^{\mathrm{T}}$ and Viridibacillus arenosi DSM $16319^{\mathrm{T}}$ had the same A4 $\alpha$ L-Lys-D-Asp peptidoglycan 
type, whereas Viridibacillus neidei NRRL BD- $87^{\mathrm{T}}$ and Bacillus pycnus NRRL BRS-1691 ${ }^{\mathrm{T}}$ (now Rummeliibacillus pycnus; Vaishampayan et al., 2009) were characterized by the L-Lys-D-Glu peptidoglycan type (Albert et al., 2007). The latter type has also been reported for Solibacillus silvestris (Rheims et al., 1999). Despite the differences in peptidoglycan type between $V$. arenosi, $V$. arvi and $V$. neidei, all three species have been assembled within a single genus, Viridibacillus. This is in concordance with Abd ElRahman et al. (2002), who did not wish to propose a new genus to accommodate Bacillus psychrodurans, Bacillus psychrotolerans and Bacillus insolitus based only upon the distinctive A4 $\beta$ L-Orn-D-Glu type alone. They reasoned that such single-parameter-based taxa are prone to be unstable and that such a proposal would be premature. However, very recently Krishnamurthi et al. (2010) did transfer these three species to the novel genus Psychrobacillus based on phenotypic, including chemotaxonomic, characteristics, and ribotype patterns. The view of Abd El-Rahman et al. (2002) is in contrast to Ahmed et al. (2007), who delineated Lysinibacillus mainly on the basis of its distinctive peptidoglycan type. A comprehensive polyphasic study of the Bacillus rRNA group 2 organisms (Ash et al., 1991) might reveal 'good' borderlines between existing genera and potential new ones, and future rearrangements within this group can be expected. However, it must be said that it is difficult to find phenotypic differences between the members of this group as they tend to be unreactive in many routine characterization tests (e.g. API $50 \mathrm{CHB}$ and API Biotype $100 \mathrm{kits}$ ). L. macroides, for example, is unreactive in API $50 \mathrm{CHB}$ and $20 \mathrm{E}$ tests and did not show growth on most of the carbon sources in the Biotype 100 carbon source assimilation gallery (bioMérieux). Using the Biolog Gen III system, strains L. macroides LMG $18474^{\mathrm{T}}$, L. boronitolerans DSM $17140^{\mathrm{T}}$, L. sphaericus LMG $7134^{\mathrm{T}}$, L. fusiformis LMG $9816^{\mathrm{T}}$ and L. xylanilyticus CCUG $57438^{\mathrm{T}}$ reacted positively for utilization of inosine, Larginine, L-glutamic acid, L-histidine, L-serine, methyl pyruvate, D-lactic acid methyl ester, L-lactic acid, Tween 40, $\alpha$-hydroxybutyric acid, $\beta$-hydroxy-DL-butyric acid, $\alpha$ ketobutyric acid, diacetic acid and acetic acid. Strains were sensitive to fusidic acid, troleandomycin, minocycline, lincomycin, sodium tetradecyl sulfate, vancomycin, tetrazolium violet and tetrazolium blue. L. macroides LMG $18474^{\mathrm{T}}$ could be differentiated from its closest neighbours based on the Biolog Gen III system by its sensitivity to lithium chloride, aztreonam and sodium butyrate; additional differential characters based on Biolog Gen III are given in Table 1. Bennett \& Canale-Parola (1965) reported ' $B$. macroides' as negative for the Voges-Proskauer test and weakly positive for gelatin hydrolysis, but $L$. macroides LMG $18474^{\mathrm{T}}$ reacted positively for Voges-Proskauer and did not hydrolyse gelatin. Logan \& De Vos (2009) repeated the comment of Claus \& Berkeley (1986) that the endospore of ' $B$. macroides' is frankly oval and scarcely distends the sporangium, a character that distinguishes it from $B$. sphaericus ( $=L$. sphaericus). However, in the present work, the endospore and sporangial morphologies of L. macroides
LMG $18474^{\mathrm{T}}$ were not observed to be distinctly different from those of L. sphaericus (Fig. 2 and Fig. S4 available in IJSEM Online). The major fatty acid for L. macroides LMG $18474^{\mathrm{T}}$ was iso- $\mathrm{C}_{15: 0}(45.3 \pm 4.6 \%)$. Moderate amounts of iso- $\mathrm{C}_{16: 0}(12.8 \pm 0.6 \%), \mathrm{C}_{16: 1} \omega 7 c$ alcohol $(12.3 \pm 2.0)$, anteiso- $\mathrm{C}_{15: 0}(7.9 \pm 3.0 \%), \mathrm{C}_{16: 1} \omega 11 c(7.2 \pm 2.0 \%)$ and iso- $\mathrm{C}_{14: 0}(5.1 \pm 1.1 \%)$ were detected, whereas minor to trace amounts of iso- $\mathrm{C}_{17: 0}(3.3 \pm 0.5 \%)$, anteiso- $\mathrm{C}_{17: 0}$ $(1.8 \pm 0.6 \%), \mathrm{C}_{16: 0}(1.7 \pm 0.8 \%)$, iso- $\mathrm{C}_{17: 1} \omega 10 c(1.3 \pm 0.8)$ and $\mathrm{C}_{14: 0}(<1.00 \%)$ were observed. These values (based on four replicate profiles of strain LMG $18474^{\mathrm{T}}$ ) confirm the placement of strain LMG $18474^{\mathrm{T}}$ in the genus Lysinibacillus, which is characterized by iso- $\mathrm{C}_{15: 0}$ as the major fatty acid (Ahmed et al., 2007). Furthermore, fatty acid profiles of the type strains of neighbouring species have been generated and are presented in Table S1 (available in IJSEM Online). Different relative amounts of anteiso- $\mathrm{C}_{15: 0}$ allow differentiation of L. macroides LMG $18474^{\mathrm{T}}$ from L. boronitolerans DSM $17140^{\mathrm{T}}$ and $L$. fusiformis LMG $9816^{\mathrm{T}}$; L. macroides LMG $18474^{\mathrm{T}}$ can be differentiated from L. xylanilyticus CCUG $57438^{\mathrm{T}}$ based on a lower amount of iso- $\mathrm{C}_{15: 0}$. A higher relative abundance of $\mathrm{C}_{16: 1} \omega 7 c \mathrm{alcohol}$ and the absence of anteiso- $\mathrm{C}_{17: 0}$ and $\mathrm{C}_{16: 0}$ differentiated L. sphaericus LMG $7134^{\mathrm{T}}$ from $L$. macroides LMG $18474^{\mathrm{T}}$. Major polar lipids for L. macroides LMG $18474^{\mathrm{T}}$ and $L$. boronitolerans DSM $17140^{\mathrm{T}}$ were diphosphatidylglycerol, phosphatidylglycerol and phosphatidylethanolamine. Phosphoaminolipids (PAL1 to 4) and unknown lipids (L1 to 5) have also been detected in minor amounts; both profiles were highly similar but phosphoaminolipid PAL1, detected in LMG $18474^{\mathrm{T}}$, was not present in DSM $17140^{\mathrm{T}}$ (Fig. S5a and b, available in IJSEM Online). This profile matches the polar lipid profile described for the genus Lysinibacillus with diphosphatidylglycerol and phosphatidylglycerol as the major components (Ahmed et al., 2007). However, glycolipids, which are typical for members of the genera Bacillus, Paenibacillus and Cohnella (Kämpfer et al., 2006), were not detected in this study, although Ahmed et al. (2007) reported on a ninhydrin-positive phosphoglycolipid. The profile of $L$. macroides LMG $18474^{\mathrm{T}}$ is much more complex than the profile of Kurthia species as reported by Goodfellow et al. (1980), enabling their distinction. Phenotypic and chemotaxonomic data allow the differentiation of L. macroides from other Lysinibacillus species as shown in Table 1.

Based on the data discussed above, ' $B$. macroides' strain LMG $18474^{\mathrm{T}}$ is proposed as Lysinibacillus macroides sp. nov., nom. rev.

\section{Lysinibacillus macroides sp. nov., nom. rev.}

Lysinibacillus macroides [ma.cro.i'des. Gr. adj. makros large or long; Gr. suff. -eides (from Gr. n. eidos form or shape) resembling, similar; N.L. masc. adj. macroides long in form, describing the elongated appearance of the rods].

Description is based on a single strain. Strictly aerobic, Gram-positive and Gram-negative motile rods. Cell size is 
Table 1. Characteristics that differentiate L. macroides from the type strains of other Lysinibacillus species

All data are from this study. Strains: 1, Lysinibacillus macroides LMG $18474^{\mathrm{T}} ; 2$, Lysinibacillus boronitolerans DSM $17140^{\mathrm{T}} ; 3$, Lysinibacillus sphaericus LMG $7134^{\mathrm{T}}$; 4, Lysinibacillus fusiformis LMG $9816^{\mathrm{T}}$; 5, Lysinibacillus xylanilyticus CCUG $57438^{\mathrm{T}}$. All type strains gave positive results for motility, growth without $\mathrm{NaCl}$, catalase activity and Voges-Proskauer test, and negative results for $\mathrm{H}_{2} \mathrm{~S}$ production, $\beta$-galactosidase (ONPG) and indole production. +, Positive reaction; -, negative reaction; w, weak reaction; $-/$ w, negative or weakly positive; $v$, variable; ND, no data available.

\begin{tabular}{|c|c|c|c|c|c|}
\hline Characteristic & 1 & 2 & 3 & 4 & 5 \\
\hline Cell length $(\mu \mathrm{m})$ & $3.0-100^{*}$ & $3.0-5.0$ & $1.5-5.0$ & $1.5-5.0$ & $3.0-5.0$ \\
\hline Gram reaction & $\mathrm{V}$ & + & + & $\mathrm{V}$ & + \\
\hline $10{ }^{\circ} \mathrm{C}$ & $\mathrm{w}$ & - & + & - & + \\
\hline $45^{\circ} \mathrm{C}$ & + & + & - & - & - \\
\hline \multicolumn{6}{|l|}{ Growth in/at: } \\
\hline $7 \%(\mathrm{w} / \mathrm{v}) \mathrm{NaCl}$ & - & - & - & + & - \\
\hline $\mathrm{pH} 6.0$ & - & + & + & + & + \\
\hline Oxidase & - & + & + & + & + \\
\hline Nitrate reduction & - & - & + & - & + \\
\hline L-Arginine dihydrolase & - & $\mathrm{w}$ & $\mathrm{w}$ & - & - \\
\hline \multicolumn{6}{|l|}{ Hydrolysis of: } \\
\hline \multicolumn{6}{|l|}{ Acid production from: } \\
\hline$N$-Acetyl-D-glucosamine & - & + & - & + & - \\
\hline$N$-Acetyl- $\beta$-D-mannoside & - & + & + & + & + \\
\hline D-Glucose & - & - & - & $\mathrm{w}$ & - \\
\hline \multicolumn{6}{|l|}{ Utilization of: } \\
\hline Citrate & $\mathrm{w}$ & - & + & + & $\mathrm{w}$ \\
\hline Raffinose & + & + & - & + & - \\
\hline Glycerol & - & - & + & - & + \\
\hline D-Fructose 6-phosphate & - & + & - & + & - \\
\hline D-Gluconic acid & + & + & - & + & - \\
\hline Propionic acid & + & - & + & + & + \\
\hline
\end{tabular}

${ }^{*}$ L. macroides produces long filaments in broth culture.

$0.9-1.1 \times 3.0-5.0 \mu \mathrm{m}$ on plate cultures, but long filaments of $10-100 \mu \mathrm{m}$ or more may be formed in broth cultures. Endospores form within $24-48 \mathrm{~h}$ of incubation at $30{ }^{\circ} \mathrm{C}$ on TSA containing $5 \mathrm{mg} \mathrm{MnSO}_{4} \mathrm{l}^{-1}$. Endospores are ellipsoidal but nearly spherical, lie terminally or subterminally and may swell the sporangia slightly; sporangia readily become ghost cells and endospores are released early. After $24 \mathrm{~h}$ incubation at $30{ }^{\circ} \mathrm{C}$ on TSA, colonies are moist and loose in texture, circular in shape, cream in colour, with irregular edges and glossy surfaces, and have diameters of $0.5-1.0 \mathrm{~mm}$; colonies reach $3.0-5.0 \mathrm{~mm}$ in diameter after $48 \mathrm{~h}$. Growth occurs at $\mathrm{pH} 7.0-9.0$, with optimum growth occurring at $\mathrm{pH} 8.0$; no growth occurs at $\mathrm{pH}$ 6.0. Growth occurs between $20{ }^{\circ} \mathrm{C}$ and $45^{\circ} \mathrm{C}$; growth is weak at $10{ }^{\circ} \mathrm{C}$ and optimum growth occurs at $30^{\circ} \mathrm{C}$. Grows in the presence of $0 \%(\mathrm{w} / \mathrm{v}) \mathrm{NaCl}$ and in up to $4 \%(\mathrm{w} / \mathrm{v})$ $\mathrm{NaCl}$, but not in $5 \%(\mathrm{w} / \mathrm{v})$. Aesculin, casein and starch are not hydrolysed. Catalase production is positive and oxidase production is negative. The Voges-Proskauer (acetoin production) test is positive, but citrate utilization, gelatin hydrolysis, nitrate reduction, and L-arginine dihydrolase, hydrogen sulfide, indole, lysine decarboxylase, ornithine decarboxylase, ONPG, tryptophan deaminase and urease production are negative. Does not produce acid or gas from carbohydrates. The amino acids L-histidine and L-proline, and the organic acids citrate, DL-lactate and $\beta$-hydroxybutyrate, are weakly assimilated. Raffinose, D-gluconic acid and propionic acid are also assimilated. Cell wall peptidoglycan is of the A $4 \alpha$ L-Lys-D-Asp type. Major polar lipids are diphosphatidylglycerol, phosphatidylglycerol and phosphatidylethanolamine. 


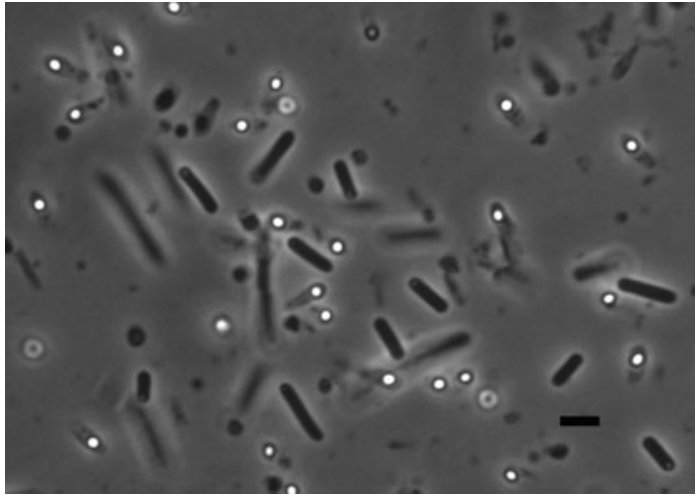

Fig. 2. Photomicrograph of sporangia and vegetative cells of the type strain of $L$. macroides LMG $18474^{\top}$, viewed by phasecontrast microscopy; spherical and slightly ellipsoidal spores lie terminally and subterminally in sporangia that are slightly swollen. Bar, $2 \mu \mathrm{m}$.

The predominant fatty acid is iso- $\mathrm{C}_{15: 0}$; moderate amounts of iso- $\mathrm{C}_{16: 0}$ and $\mathrm{C}_{16: 1} \omega 7 c$ alcohol are present.

The type strain is LMG $18474^{\mathrm{T}}$ (=DSM $54^{\mathrm{T}}=$ ATCC $\left.12905^{\mathrm{T}}\right)$, which was isolated from cow dung. The DNA $\mathrm{G}+\mathrm{C}$ content of the type strain is $38.2 \mathrm{~mol} \%$.

\section{Acknowledgements}

The authors are indebted to Anneleen Wieme, University College Ghent, and Freek Spitaels, Ghent University, for their valuable help in analysing MALDI-TOF profiles.

\section{References}

Abd El-Rahman, H. A., Fritze, D., Spröer, C. \& Claus, D. (2002). Two novel psychrotolerant species, Bacillus psychrotolerans sp. nov. and Bacillus psychrodurans sp. nov., which contain ornithine in their cell walls. Int J Syst Evol Microbiol 52, 2127-2133.

Ahmed, I., Yokota, A., Yamazoe, A. \& Fujiwara, T. (2007). Proposal of Lysinibacillus boronitolerans gen. nov. sp. nov., and transfer of Bacillus fusiformis to Lysinibacillus fusiformis comb. nov. and Bacillus sphaericus to Lysinibacillus sphaericus comb. nov. Int J Syst Evol Microbiol 57, 1117-1125.

Albert, R. A., Archambault, J., Lempa, M., Hurst, B., Richardson, C., Gruenloh, S., Duran, M., Worliczek, H. L., Huber, B. E. \& other authors (2007). Proposal of Viridibacillus gen. nov. and reclassification of Bacillus arvi, Bacillus arenosi and Bacillus neidei as Viridibacillus arvi gen. nov., comb. nov., Viridibacillus arenosi comb. nov. and Viridibacillus neidei comb. nov. Int J Syst Evol Microbiol 57, 2729-2737.

Ash, C., Farrow, J. A. E., Wallbanks, S. \& Collins, M. D. (1991). Phylogenetic heterogeneity of the genus Bacillus revealed by comparative analysis of small-subunit-ribosomal RNA sequences. Lett Appl Microbiol 13, 202-206.

Bennett, J. F. \& Canale-Parola, E. (1965). The taxonomic status of Lineola longa. Arch Mikrobiol 52, 197-205.

Claus, D. \& Berkeley, R. C. W. (1986). Genus Bacillus (Cohn 1872). In Bergey's Manual of Systematic Bacteriology, vol. 2, pp. 1105-1139.
Edited by P. H. A. Sneath, N. S. Mair, M. E. Sharpe \& J. G. Holt. Baltimore: The Williams and Wilkins Co.

Ezaki, T., Hashimoto, Y. \& Yabuuchi, E. (1989). Fluorometric deoxyribonucleic acid - deoxyribonucleic acid hybridization in microdilution wells as an alternative to membrane filter hybridization in which radioisotopes are used to determine genetic relatedness among bacterial strains. Int J Syst Bacteriol 39, 224-229.

Fortina, M. G., Pukall, R., Schumann, P., Mora, D., Parini, C., Manachini, P. L. \& Stackebrandt, E. (2001). Ureibacillus gen. nov., a new genus to accommodate Bacillus thermosphaericus (Andersson et al. 1995), emendation of Ureibacillus thermosphaericus and description of Ureibacillus terrenus sp. nov. Int J Syst Evol Microbiol 51, 447-455.

Goodfellow, M., Collins, M. D. \& Minnikin, D. E. (1980). Fatty acid and polar lipid composition in the classification of Kurthia. J Appl Bacteriol 48, 269-276.

Groth, I., Schumann, P., Weiss, N., Martin, K. \& Rainey, F. A. (1996). Agrococcus jenensis gen. nov., sp. nov., a new genus of actinomycetes with diaminobutyric acid in the cell wall. Int J Syst Bacteriol 46, 234239.

Heyrman, J., Logan, N. A., Rodríguez-Díaz, M., Scheldeman, P., Lebbe, L., Swings, J., Heyndrickx, M. \& De Vos, P. (2005). Study of mural painting isolates, leading to the transfer of 'Bacillus maroccanus' and 'Bacillus carotarum' to Bacillus simplex, emended description of Bacillus simplex, re-examination of the strains previously attributed to 'Bacillus macroides' and description of Bacillus muralis sp. nov. Int $J$ Syst Evol Microbiol 55, 119-131.

Jung, M. Y., Paek, W. K., Styrak, I. \& Chang, Y.-H. (2010a). Proposal of Lysinibacillus sinduriensis sp. nov., and transfer of Bacillus massiliensis and Bacillus odysseyi to Lysinibacillus as Lysinibacillus massiliensis comb. nov. and Lysinibacillus odysseyi comb. nov. with emended description of this genus. Int J Syst Evol Microbiol.

Jung, M. Y., Paek, W. K., Styrak, I. \& Chang, Y.-H. (2010b). Retraction. Proposal of Lysinibacillus sinduriensis sp. nov., and transfer of Bacillus massiliensis and Bacillus odysseyi to Lysinibacillus as Lysinibacillus massiliensis comb. nov. and Lysinibacillus odysseyi comb. nov. with emended descriptions of the genus. Int J Syst Evol Microbiol 60, 3003.

Kämpfer, P., Rosselló-Mora, R., Falsen, E., Busse, H.-J. \& Tindall, B. J. (2006). Cohnella thermotolerans gen. nov., sp. nov., and classification of 'Paenibacillus hongkongensis' as Cohnella hongkongensis sp. nov. Int J Syst Evol Microbiol 56, 781-786.

Krishnamurthi, S., Ruckmani, A., Pukall, R. \& Chakrabarti, T. (2010). Psychrobacillus gen. nov. and proposal for reclassification of Bacillus insolitus Larkin \& Stokes, 1967, B. psychrotolerans Abd-El Rahman et al. 2002 and B. psychrodurans Abd-El Rahman et al. 2002 as Psychrobacillus insolitus comb. nov., Psychrobacillus psychrotolerans comb. nov. and Psychrobacillus psychrodurans comb. nov. Syst Appl Microbiol 33, 367-373.

Lee, C. S., Jung, Y.-T., Park, S., Oh, T.-K. \& Yoon, J.-H. (2010). Lysinibacillus xylanilyticus sp. nov., a xylan-degrading bacterium isolated from forest humus. Int J Syst Evol Microbiol 60, 281-286.

Logan, N. A. \& De Vos, P. (2009). Bacillus Cohn 1872. In Bergey's Manual of Systematic Bacteriology, 2nd edn, vol. 3, pp. 21-128. Edited by P. De Vos, G. M. Garrity, D. Jones, N. R. Krieg, W. Ludwig, F. R. Rainey, K.-H. Schleifer \& W. B. Whitman. New York: Springer. Logan, N. A., Lebbe, L., Hoste, B., Goris, J., Forsyth, G., Heyndrickx, M., Murray, B. L., Syme, N., Wynn-Williams, D. D. \& De Vos, P. (2000). Aerobic endospore-forming bacteria from geothermal environments in northern Victoria Land, Antarctica, and Candlemas Island, South Sandwich archipelago, with the proposal of Bacillus fumarioli sp. nov. Int J Syst Evol Microbiol 50, 1741-1753.

Logan, N. A., Forsyth, G., Lebbe, L., Goris, J., Heyndrickx, M., Balcaen, A., Verhelst, A., Falsen, E., Ljungh, A. \& other authors 
(2002). Polyphasic identification of Bacillus and Brevibacillus strains from clinical, dairy and industrial specimens and proposal of Brevibacillus invocatus sp. nov. Int J Syst Evol Microbiol 52, 953-966.

Logan, N. A., Berge, O., Bishop, A. H., Busse, H.-J., De Vos, P., Fritze, D., Heyndrickx, M., Kämpfer, P., Rabinovitch, L. \& other authors (2009). Proposed minimal standards for describing new taxa of aerobic, endospore-forming bacteria. Int J Syst Evol Microbiol 59, 2114-2121.

Ludwig, W., Strunk, O., Westram, R., Richter, L., Meier, H., Yadhukumar, Buchner, A., Lai, T., Steppi, S. \& other authors (2004). ARB: a software environment for sequence data. Nucleic Acids Res 32, 1363-1371.

MacKenzie, S. L. (1987). Gas chromatographic analysis of amino acids as the $N$-heptafluorobutyryl isobutyl esters. J Assoc Off Anal Chem 70, 151-160.

Mesbah, M., Premachandran, U. \& Whitman, W. B. (1989). Precise measurement of the $\mathrm{G}+\mathrm{C}$ content of deoxyribonucleic acid by highperformance liquid chromatography. Int J Syst Bacteriol 39, 159-167.

Miwa, H., Ahmed, I., Yokota, A. \& Fujiwara, T. (2009). Lysinibacillus parviboronicapiens sp. nov., a low-boron-containing bacterium isolated from soil. Int J Syst Evol Microbiol 59, 1427-1432.

Posada, D. (2008). jModelTest: phylogenetic model averaging. Mol Biol Evol 25, 1253-1256.

Pringsheim, E. G. (1950). The bacterial genus Lineola. J Gen Microbiol 4, 198-209.

Pringsheim, E. G. \& Robinow, C. F. (1947). Observations on two very large bacteria, Caryophanon latum Peshkoff and Lineola longa (nomen provisorium). J Gen Microbiol 1, 267-278.

Rheims, H., Frühling, A., Schumann, P., Rohde, M. \& Stackebrandt, E. (1999). Bacillus silvestris sp. nov., a new member of the genus Bacillus that contains lysine in its cell wall. Int J Syst Bacteriol 49, 795-802.

Schleifer, K. H. (1985). Analysis of the chemical composition and primary structure of murein. Meth Microbiol 18, 123-156.
Schleifer, K. H. \& Kandler, O. (1972). Peptidoglycan types of bacterial cell walls and their taxonomic implications. Bacteriol Rev 36, 407-477.

Skerman, V. B. D., McGowan, V. \& Sneath, P. H. A. (1980). Approved lists of bacterial names. Int J Syst Bacteriol 30, 225-420.

Tamura, K., Peterson, D., Peterson, N., Stecher, G., Nei, M. \& Kumar, S. (2011). MEGA5: molecular evolutionary genetics analysis using maximum likelihood, evolutionary distance, and maximum parsimony methods. Mol Biol Evol 28, 2731-2739.

Tindall, B. J. (1990a). Lipid composition of Halobacterium lacusprofundi. FEMS Microbiol Lett 66, 199-202.

Tindall, B. J. (1990b). A comparative study of the lipid composition of Halobacterium saccharovorum from various sources. Syst Appl Microbiol 13, 128-130.

Vaishampayan, P., Miyashita, M., Ohnishi, A., Satomi, M., Rooney, A., La Duc, M. T. \& Venkateswaran, K. (2009). Description of Rummeliibacillus stabekisii gen. nov., sp. nov. and reclassification of Bacillus pycnus Nakamura et al. 2002 as Rummeliibacillus pycnus comb. nov. Int J Syst Evol Microbiol 59, 1094-1099.

Vancanneyt, M., Witt, S., Abraham, W. R., Kersters, K. \& Fredrickson, H. L. (1996). Fatty acid content in whole-cell hydrolysates and phospholipid fractions of pseudomonads: a taxonomic evaluation. Syst Appl Microbiol 19, 528-540.

Weon, H.-Y., Lee, S.-Y., Kim, B.-Y., Noh, H.-J., Schumann, P., Kim, J.-S. \& Kwon, S.-W. (2007). Ureibacillus composti sp. nov. and Ureibacillus thermophilus sp. nov., isolated from livestock-manure composts. Int J Syst Evol Microbiol 57, 2908-2911.

Willems, A., Doignon-Bourcier, F., Goris, J., Coopman, R., de Lajudie, P., De Vos, P. \& Gillis, M. (2001). DNA-DNA hybridization study of Bradyrhizobium strains. Int J Syst Evol Microbiol 51, 13151322.

Xu, D. \& Côté, J.-C. (2003). Phylogenetic relationships between Bacillus species and related genera inferred from comparison of $3^{\prime}$ end $16 \mathrm{~S}$ rDNA and $5^{\prime}$ end 16S-23S ITS nucleotide sequences. Int $J$ Syst Evol Microbiol 53, 695-704. 